\title{
Friedrich Schleiermacher's Reden and the problem of religious plurality
}

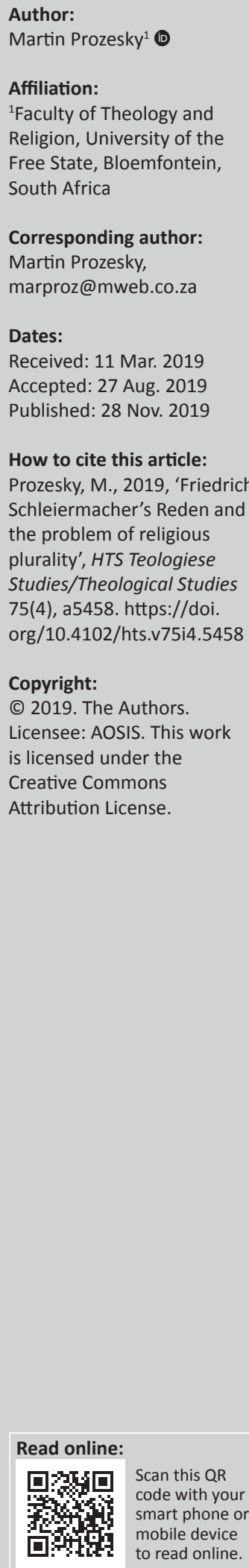

\begin{abstract}
Modern knowledge of the world's religions brings to light the problem of religious plurality, meaning the problem of why there is such great religious diversity, and which set of religious beliefs, if any, can be judged to be true. In 1799 and in the later editions, the young Friedrich Schleiermacher (1768-1834) offered a pioneering account of religion in his revolutionary work, widely known as the Reden, first rendered in English in 1893 with the title On Religion: Speeches to Its Cultured Despisers, which this article summarises and critically evaluates in relation to that problem. Guided by the work of Eric Sharpe on the history of the comparative study of religion, the article locates Schleiermacher in the context of the state of knowledge about the plurality of religions when he wrote the Reden, compared to our present knowledge. The evaluation takes as its primary critical criteria the requirements of the academic study of religions, not the theological interests relevant to Schleiermacher as a Christian thinker. The evaluation yields a mixed verdict, noting four significant strengths in Schleiermacher's account of religion but also three important limitations, the main one arising, understandably, from his personal faith, but nonetheless a problem in the academic study of religions.
\end{abstract}

Keywords: Schleiermacher; Religious plurality; Comparative religion; On religion; Eric Sharpe.

\section{Introduction}

The question explored in the present article is how well Schleiermacher's account of religion in his early work accounts for what has been called the problem of religious plurality and its underlying issue of an adequate knowledge of the nature of the religions. The problem arises for the rigorous truth-seeker from the fact that the world is home to a vast range of religions that offer different and at times contradictory accounts of the ultimate reality and about what, if anything, awaits us when we die, apart from bodily dissolution.

As a logical consequence of religious diversity, the world's religions cannot all be true. At best, only one could be true, giving rise to the problem of determining which one it is according to the principles of factual and logical adequacy. Moreover, the religions could, as secularists aver, all be mistaken, if that can be shown by the same principles of academic enquiry. Such is the problem generated by the reality of a divergent religious plurality.

This problem has existed for as long as religious diversity has existed, probably for most of the time Homo sapiens have existed, now reckoned by scientists to be about 200000 years (McCarthy \& Rubidge 2005:293). It is, however, only in the past few centuries that the problem could be recognised and answers offered, once awareness of the diversity arose and once critical reasoning from the European Enlightenment onwards began to cast doubts on the claim by a particular religion to be the only true faith.

This article is based on the revises part of a chapter submitted to a Festschrift in honour of the doyen of Schleiermacher studies in the English-speaking world, Terrence N. Tice (Richardson \& Lawler 1997). It is concerned only with the account Schleiermacher gave in 1799 and again in 1806 in his influential early work, the Reden, first translated to English in 1893 with the title On Religion: Speeches to Its Cultured Despisers. As such, the article also draws on certain journal articles of mine about that part of Schleiermacher's life and work (Prozesky 1980, 1981). Pünjer's critical edition of the Reden of 1879 is used for references to that work, otherwise Tice's 1969 translation.

After Schleiermacher's Moravian schooling and university studies at Halle, mainly in philosophy, and 5 or 6 years of short-term work, he moved to Berlin in 1796 as a Reformed chaplain at the Charité Hospital. 
Among his new friends in Berlin were members of the city's intellectual elite, with dismissive views of religion. It was these views that prompted him to write the Reden, issued anonymously in 1799. Before his contentions are presented and evaluated, it is necessary to comment on both the phenomenon of religious plurality and the critical, academic study of the religions, then and now.

\section{The plurality of religions}

As already indicated, our human world has probably been home to a diversity of faiths since the beginnings of different human communities and cultures. The gradual emergence of the academic study of religion, operating independently of theology, over the past 150 years, has enabled us to know that while some faiths show a strong mutual resemblance, like the three monotheistic Abrahamic faiths, others are markedly different, such as those of China. To illustrate the diversity, we can note that for Australia's first people, the Dreamtime is the ultimate reality; for many Buddhists, it is sunyata or Emptiness; for the San, it is Kagn; and for Christians, it is the Holy Trinity. In his still highly influential 1989 interpretation of the way in which the object of religious belief, which he terms the Real, is understood both theistically and nontheistically, John Hick has termed this great divergence 'the Personae of the Real' and 'the Impersonae of the Real', respectively (Hick 1989:252-277, 278-296).

Another important divergence among the faiths of the world concerns their teachings about an afterlife. Hindus and many Buddhists believe that the soul or atman is re-incarnated in different bodies after its present embodiment, perhaps many times. African traditionalist believers contend that the soul passes into a spirit world peopled by the ancestors, a passage requiring the observance of important rituals by the living relatives and their community (Thorpe 1991:38-41; 64-66). Judaism, Christianity and Islam teach that we live only once and at death face the reality, as they variously see it, of an afterlife in the spirit form either in the eternal presence of God or in the eternal separation from God, or worse.

Notwithstanding such important and incompatible differences, we know that these faiths are all able to hold the allegiance of their followers, sometimes for millennia. In all of them, a similar personal characteristic of religious faith is also to be discerned, that of profound, over-riding attachment to the object of faith. Wilfred Cantwell Smith's characterisation of that object as 'a transcendent dimension' remains definitive for its ability to cover such great differences of concept as a personal deity and the impersonal Brahman of classical Upanishadic Hinduism (Smith 1979:12).

How are scholars to account for both the diversity and the allegiance? Paul Tillich famously proposed that to be religious, to have faith, is to be gripped by an ultimate concern, but why does humanity have such different and even contradictory beliefs about what is ultimate? (Tillich 1957) That is the problem of religious plurality.
More than 150 years before Tillich, the young Friedrich Schleiermacher proposed a view of religion that might provide an academically acceptable answer to the abovementioned problem, in his famous early publication called Über die Religion: Reden an die Gebildeten unter Ihren Verächtern. This article summarises and critically evaluates that view, but before doing so it is necessary to note the state of knowledge about the religions at that time. Only then can Schleiermacher's contribution be fairly judged. Eric Sharpe provides a detailed account of this in his important book, Comparative Religion: A History, on which the following paragraphs are based (Sharpe 1986:1-32).

Compared to the knowledgenow available to an undergraduate student from an introductory semester course on the religions, in Schleiermacher's day, only a very narrow understanding was available, at best, especially in Christian circles like his. Much more influential in hampering the rise of a reliable account of other religions at that time, and for many centuries before it, was the 'exclusiveness and intolerance', according to Sharpe, of both Judaism and Christianity, ruling out any possibility of objective data about other religions, because all were dismissed as dangerous and wrong, being considered as the work of either devils or fallen angels (Sharpe 1986:7).

Comparative religion, which is Sharpe's preferred designation for this field of study, is by contrast 'the historical, critical and comparative study of the religions of the world', and it only emerged in the 1860s and 1870s (Sharpe 1986:1), thus coming long after Schleiermacher's day. Sharpe helpfully notes that this new field of research and study required three elements: a motive, a material and a method (Sharpe 1986:2).

The motive is critical discontent of some kind with the religion of the culture concerned, which the philosophical reasoning of Enlightenment thinkers had already highlighted, but it dates back to the thinkers of classical Greece, such as Xenophanes of Colophon, who were known to have criticised the local religion for its crude anthropomorphism, and Herodotus, whose travels enabled him to observe and describe the religions of the Persians and the Egyptians (Sharpe 1986:4). Schleiermacher's studies of ancient Greek culture and its language, and of philosophy, would have made him well aware of this heritage of critical thinking about religion as a problem, and it enabled him to discern critical problems in the Christian beliefs that had nurtured him. He therefore had an academically valid motive for proposing a new understanding of the nature of religion in general and also of his own Christian faith.

As for the second element on which comparative religion which I also call the academic study of religion - depends, namely, reliable material, a growing body of it had accumulated in Christian Europe over many centuries, starting with a measure of awareness of the faiths and philosophies of the Graeco-Roman world of classical antiquity. Judaism was of course no stranger to Christians from the very beginning of their faith, but was generally seen 
by Christians, then as even now, as having been superseded by their own faith and thus of no religious importance and very little scholarly value. Of even a lesser interest, except as a dangerous foe, was Islam, against which violent crusades had been waged with church blessing. As Sharpe remarks, Christians mostly regarded Judaism with a 'mixture of pity and disgust and Islam with a mixture of fear and hatred', and neither was known accurately (1986:12).

As for the religions of Asia, the travels of Marco Polo and others from the 13th century onwards brought knowledge of lands like Persia and especially China to the Christian West. Zwi Werblowsky, the distinguished historian of religions at the Hebrew University in Jerusalem, explained to his hosts during his time as a visiting professor in Religious Studies at the former University of Natal in August 1986 that the knowledge about the sophistication of the Chinese culture and religions that was brought back by those travellers was so impressive that Christians, evidently threatened by the quality of the Asian religions, declined to recognise them as religion at all and rather called them civilisations. All the same, sound accounts of Asian religions had begun to be available in Europe. Somewhat later, the so-called voyages of discovery to the Americas and the Far East brought awareness of the religions of those regions, but little sympathy for them. Catholic missions to China by Matteo Ricci and others brought additional valuable knowledge of Chinese and Japanese religions to Catholic Europe (Sharpe 1986:14-15).

Christian Europe by about 1700 regarded the religions of other parts of the world like Africa as paganism and had little or no knowledge of them. Protestant missions from the 18th century onwards, like those of the Moravians, would change that as missionary contact with African cultures made awareness of their religions possible. While Britain's presence in India from about 1750 made a growing scholarly knowledge of Hinduism available in English, little of this was available in German until later with the work of Schleiermacher's friend, the controversial and gifted literary figure Friedrich Schlegel, published in 1808. Whether any of this found its way into the Protestant world of Friedrich Schleiermacher in the late 1790s is unclear. So at the end of the eighteenth century, even the intellectuals in Germany had little or no knowledge of religions other than Christianity, Judaism and Islam.

It was only with the work of Friedrich Max Müller, working at Oxford in the 1860s, that comparative religion as a serious academic field of study could get under way (Sharpe 1986:27-28). It was he who began speaking of the 'Science of Religion' and who authored the classic principle of the academic study of religions: 'He who knows one, knows none', in his Introduction to the Science of Religion of 1873 (Sharpe 31). That therefore happened over 70 years after Schleiermacher published the first edition of his Reden.

What Sharpe's survey of the slow and very uneven growth in Europe of reliable information about religions other than Christianity shows, in connection with Schleiermacher, is that he had very little material to work with by today's standards to guide him when he set out to give his account of the nature of religion. This was no fault of his, of course, for comprehensive information about the plurality of religions was just not available back then. So while it would clearly be unreasonable to expect in his account any great knowledge of religions other than his own, of classical Greece and of Judaism, it is fair to ask how adequately he handled what was then evident from his admittedly limited knowledge, namely, the reality of a divergent plurality of faiths and their common ability to evoke and hold the profound loyalty of their adherents.

This brings the present article to the third of the elements in the academic study of religion, namely, method. The next section of the article summarises Schleiermacher's way of accounting for religion, while the critical discussion that follows evaluates it for the academic study of religions today.

\section{Schleiermacher's account of religion in the Reden}

Schleiermacher addressed the question of the nature or essence (das Wesen) of religion in the second of the discourses or speeches that make up the Reden. His account of actual religions, namely, Judaism and Christianity, comes in the fifth speech and is not my main concern in this article. About the nature of religion, he offered five main contentions.

Firstly, religion (later termed 'piety'/Frömmigkeit) always appears in combination with two other great human concerns but is neither of them (Schleiermacher 1799:33, 43) As a result, secondly, religion is often confused with those two realities, which are metaphysics and morality. In the 1806 and 1821 revisions, Schleiermacher retained this assertion, wording it that piety must not be confused with knowledge and morality.

The third point is the most important. It asserts that religion itself is 'sense and taste for the infinite', which immediately becomes a matter of perceiving and feeling the universal (Anschauung und Gefühl des Universums), in and through the finite. He reworded this idea into a more theistic version in 1806 and 1821, calling piety a feeling of God's operation in us by means of the universe, immediately experienced. In his explanatory notes of 1821, Schleiermacher wrote, 'At its very roots religion is feeling (Gefühl) roused towards man's highest end' (Schleiermacher 1821:136, 160).

His fourth contention is that the beliefs and doctrines of religion are inevitable conceptual expressions of religious experience but, being forms of purported metaphysical knowledge, they are not the heart of religion at all (Schleiermacher 1799:114). They arise, he added in 1806 and 1821, from subsequent reflection upon the essence of religion.

In the often neglected 1799 edition, Schleiermacher added the controversial contention, for a Christian minister especially, that religion does not depend upon the concept of God and that a religion without that concept can be better 
than one with it (Schleiermacher 1799:124-125). He wrote that, 'God is not everything in religion; God is one thing, universality is more'.

In keeping with the shift to a more theistic turn in the later editions of the Reden, this original contention was revised into the idea that the divine reality is indeed implied in all that Schleiermacher had been saying, so that it is just the concept of God that is historically and culturally contingent. According to Schleiermacher, the familiar, personal concept of God arises when a culture's dominant sense of reality is defined by freedom, because personal existence is our leading model of freedom. Note again how for Schleiermacher felt experience underlies the beliefs of religion, not the other way around.

The fifth of the points is Schleiermacher's 1799 contention that each religion involves a distinctive world-view, as we might express the idea today. In the 1821 revision, he reworded the idea by writing that each religion has a distinctive way of relating to the Supreme Being.

\section{Critical discussion: Positive aspects}

In evaluating Schleiermacher's account of religion in the light of religious plurality, it is important to emphasise his extremely limited knowledge of the extent of the plurality, though no fault of his own. He was of course very well aware of the differences between the Moravian pietism of his schooldays, his own Reformed tradition and the dominant Lutheranism of Prussia. He was also well acquainted with Jewish friends in Berlin and with what we would today call the city's secular intelligentsia, the 'cultured despisers' of religion to whom he addressed the Reden, people like his close atheist friend at the time, the celebrated writer and literary theorist Friedrich Schlegel, who later became Germany's first scholarly authority on Hinduism, as has already been noted.

Four important strengths can be identified in Schleiermacher's account of religion, over 200 years later, despite his very limited knowledge of the various religions.

Firstly, his account is remarkably advanced given the state of the prevailing views of and knowledge about religion, these being either sceptical dismissal of all religions or uncritical and poorly informed adherence to a personal faith. This strength is best seen in the way he was able to address the fact of religious plurality by using concepts like 'sense and taste for the infinite' (further explained in the paragraph below about the fourth merit of Schleiermacher's view of the religions), concepts that do not belong to the special vocabulary of any of the religions, and especially not to his own.

Secondly - and here we touch again on the vital issue of method - Schleiermacher's view of religion arose from firsthand knowledge, not classroom or book knowledge; it was enough to reveal a critically important fact: moral goodness, spiritual depth and intellectual power are present in all the religious traditions he had experienced. He knew that diversity of belief is just a fact about religion, not sameness, and that it is compatible with an equivalence of moral and spiritual quality and intellectual competence on the part of the believers in the traditions he knew.

Today's portrayal of religions by arguably the most important authority on the problem of religious plurality, John Hick, confirms Schleiermacher on this point, as shown in great detail in his 1989 book, The Interpretation of Religion. Direct, personal experience of religious diversity is thus the most important positive feature in Schleiermacher's method of interpreting religion, for it enabled his account to accommodate the basic reality of religious plurality. $\mathrm{He}$ clearly understood that a viable account of the nature of religion must accommodate that divergent plurality.

The third strength is just as important as the second. We all know that religion involves more than all that even the most careful student can note about it through observation, for religion always involves a subjective, inner dimension in the experience of the believer. The ability to do justice to what others experience in their faith is therefore an essential part of an adequate method of understanding any religion. As we never have direct access to the experiences of others, the best we can do is come as close and as fairly to it as any outsider can. That requires informed empathy. The concept of empathy was probably unknown in Berlin in 1799 and elsewhere, but what it involves was not: the ability to enter fairly and thoroughly into the views and values of others, and not be biased by one's own.

Schleiermacher had that skill, even though it has not been methodologically articulated or even made explicit in the Reden. It can, however, be inferred from the way he addressed those who dismiss religion in that book, doing so with insight and understanding even though he argued that they did not truly understand what they dismissed. His empathetic skill, to use today's terms, is however best seen in two other sources, his letters and his little book Christmas Eve, which he wrote as a gift for his friends, about which Lloyd Geering has published an appreciative recent account (Schleiermacher 2010; Geering 2018).

Much of Schleiermacher's long and detailed correspondence survives in published form (Dilthey \& Jonas 1860-1863), and it shows a fine capacity for friendship. This capacity depends on the willingness and ability to truly listen to your friends, to understand and care about them, sensing something of their happiness, their anxieties and their pain. That is the foundation of informed empathy. So here again Schleiermacher can be seen as a remarkable pioneer in the way to study religion, this time in connection with a valuable, empathetic method of appreciating and understanding what faith means to others, including those from a different religious tradition.

The fourth strength comes from the heart of Schleiermacher's account in the Reden, his view that religion itself is 'sense and taste for the infinite', which immediately becomes a matter of perceiving or contemplating, and feeling the universe 
(Anschauung und Gefühl des Universums), in and through the finite. My understanding of his use of the word Universum is that it does not mean the physical universe of scientific investigation, but the totality of all that is the case, perhaps revealing his debt to Spinoza's monistic theism, sometimes miscalled pantheism.

Whatever else religion worldwide is, it always involves feeling, as later confirmed empirically in William James' classic study of religious experience, and in Alister Hardy's account on the nature of spiritual experience (Hardy 1979; James 1902). Without their much greater knowledge of the world's religions, Schleiermacher accurately identified a key characteristic of what religious faith everywhere involves, surely a remarkable achievement.

The lasting importance of his identification of feeling at the heart of religious experience is this: it explains both what religions have in common and why they differ. In common is the fact that it is human nature everywhere and always to feel something deep, rich, loyal and good when touched by that which engenders such feelings more powerfully than anything else and to ally ourselves lastingly with it; and it is also just as natural that our minds will try to name and understand it with the words and concepts our different cultures offer, giving rise to the differences so characteristic of the world's religious beliefs and rituals.

\section{Negative aspects}

Three important problems can be identified in the account of religion in the Reden. The first is its account of the beliefs of actual religions, which is of course very limited; in fact, all Schleiermacher knew directly was Protestant Christianity and Judaism in Berlin at the time, and his account of the latter as a religion with a basically retributive relationship with its God (Schleiermacher 1799:283) is seriously suspect.

The second problem is his presentation of Christianity as the supreme religion (Schleiermacher 1799:283). From the perspective of today's Religion Studies as an academic field independent of the religions, this is biased and unacceptable, because no good reasons are given for such a judgement.

Schleiermacher merely averred that Christianity was superior to others, although without dismissing them as deluded and even evil, as many of his fellow Christians, then and even now aver, but he did not and perhaps could not give logical and factual criteria for such a judgement. While this is a definite shortcoming in the context of the academic study of religion, it is worth noting that it is only in recent years that scholars in the field, like philosophers of religion John Hick and J.E. Schellenberg, have begun to offer answers to whether any religion can objectively be judged to be true, and if so, what that religion is or could become (Hick 1989:362-380; Schellenberg 2013:72-90).

A third problem from the perspective, again, of the academic study of religions is generated by Schleiermacher's theological orientation. As Schleiermacher, the doctrinal theologian, later wrote that sound theology must satisfy a scientific or an academic as well as an ecclesiastical test, would he continue to elevate his own belief that Christianity is superior to others if his knowledge of them was as extensive, thorough, fair and sensitive as is possible today? (Schleiermacher 1928:83). Such knowledge led John Hick, among others, to a very different conclusion (Hick 1989:375). This is however a question we cannot answer for Schleiermacher.

What can be said by way of overall conclusion is that despite such problems, the young Schleiermacher nonetheless made a lastingly important contribution to a better, more inclusive, academic way of understanding religion in its divergent diversity, through the strengths identified in this article.

\section{Acknowledgements}

The author thanks Prof. Rian Venter, University of the Free State, for the support provided.

\section{Competing interests}

The author declares that they have no financial or personal relationships which may have inappropriately influenced them in writing this article.

\section{Author's contributions}

M.P. is the sole author of this research article.

\section{Ethical considerations}

This article adheres to all relevant research and publication ethics of honesty, responsibility, thoroughness, fairness and due concern for the interests of others. It is the author's own original work; contains nothing offensive, libellous or untrue; has not been published elsewhere; and is not being considered for publication elsewhere. All sources are properly acknowledged in the text and again in the bibliography.

\section{Funding information}

This study was funded by the Department of Historical and Constructive Theology, Faculty of Theology and Religion, University of the Free State.

\section{Data availability statement}

Data sharing is not applicable to this article as no new data were created or analysed in this study.

\section{Disclaimer}

The views and opinions expressed in this article are those of the author and do not necessarily reflect the official policy or position of any affiliated agency of the author. 


\section{References}

Dilthey, W. \& Jonas, L. (eds.), 1860-1863, 1974, Aus Schleiermachers Leben, in Briefen, 4 vols, Reimer, Berlin.

Geering, L., 2018, 'Theology before and after Bishop Robinson's Honest to God (1963)', Journal for the Study of Religion 31(1), 224-236. https://doi.org/10.17159/2413 3027/2018/v31n1a12

Hardy, A., 1979, The spiritual nature of man: A study of contemporary religious experience, Clarendon Press, Oxford.

Hick, J., 1989, The interpretation of religion: Human responses to the transcendent, Macmillan, London.

James, W., 1902, The varieties of religious experience: A study in human nature, Longmans, London.

McCarthy, T. \& Rubidge, B., 2005, The story of earth and life: A southern African perspective on a 4.6-billion year journey, Struik, Cape Town.

Prozesky, M., 1980, 'Friedrich Schleiermacher's earliest account of religious experience', Religion in Southern Africa 1(2), 71-86.

Prozesky, M., 1981, 'The young Schleiermacher: Advocating religion to an age of critical reason', Journal of Theology for Southern Africa 37, 50-75.

Pünjer, B., 1879, Critical edition of Friedrich Schleiermacher, Über die Religion: Reden an die Gebildeten unter ihren Verächtern, s.n., Braunschweig.
Richardson, R.D. \& Lawler, E., 1997, Understanding Schleiermacher: From translation to interpretation: A festschrift in honor of Terrence N. Tice, The Edwin Mellor Press, Lewiston.

Schleiermacher, F.D.E., 1799, Über die Religion: Reden an die Gebildeten unter ihren Verächtern, Reimer, Berlin.

Schleiermacher, F.D.E., 1806, Über die Religion: Reden an die Gebildeten unter ihren Verächtern, 2nd revised edn., Reimer, Berlin.

Schleiermacher, F.D.E., 1821, Über die Religion: Reden an die Gebildeten unter ihren Verächtern, 3rd revised edn., Reimer, Berlin.

Schleiermacher, F.D.E., 1928, The Christian faith, English translation of the second German edition, T\&T Clark, Edinburgh.

Schleiermacher, F.D.E. 1969, On religion: Addresses in response to its cultured despisers, transl. T.N. Tice, John Knox, Richmond, Virginia, VA.

Schleiermacher, F.D.E., 2010, Christmas Eve celebration: A dialogue, transI. T.N. Tice, Cascade Books, Salem, OR.

Schellenberg, J.L., 2013, Evolutionary religion, Oxford University Press, Oxford.

Sharpe, E., 1986, Comparative religion: A history, Duckworth, London.

Smith, W.C., 1979, Faith and belief, Princeton University Press, Princeton, NJ.

Thorpe, S.A., 1991, African traditional religions, University of South Africa, Pretoria.

Tillich, P., 1957, Dynamics of faith, Harper, New York. 